\title{
The Downhill Trend in Commitment Mechanism of EU Competition Law: Empirical Evidence
}

\author{
Fatih Buğra Erdem*
}

\begin{abstract}
The European Commission has been given the authority to make commitments of undertakings in question binding with Article 9 of Regulation 1/2003. By this reform, there has been a significant increase in commitment decisions compared to prohibition decisions over time, but prohibition decisions are currently predominant again. This study discusses this downward trend in commitment decisions taken in EU competition law from 2004 to 2020 by reviewing legal developments through statistically examining the case law. Although the increase in commitment decisions is deemed beneficial in practical terms, it has increased legal uncertainties in the long run and the provision of effective competition is left to negotiations to be reached between the undertakings and the Commission, instead of a thorough application of competition law rules in a uniform and consistent manner. In this context, discussions and recommendations are presented concerning under which circumstances commitment decisions are more appropriate to make.
\end{abstract}

Keywords: EU Competition Law, Commitment Decisions, Policy Evaluation.

\section{AB Rekabet Hukuku Açısından Taahhüt Mekanizmalarının Kullanımında Düşüş̧ Eğilimi: Ampirik Bulgular}

\section{Öz}

Avrupa Komisyonu'na 1/2003 sayılı Tüzüğün 9. maddesi ile birlikte ilgili teşebbüslerin sunmuş oldukları taahhütleri bağlayıcı hale getirme yetkisi tanınmıştır. Bu reform neticesinde, taahhüt kararlarında ihlal kararlarına nazaran zaman içerisinde belirgin bir artış görülmüş olsa da, son zamanlarda ihlal kararlarında yeniden yoğunluk kazanmıştır. Bu çalışmada, Avrupa Birliği (AB) rekabet hukukunda 20042020 yılları arasında verilen taahhüt kararlarındaki düşüş eğilimi, ilgili içtihadın hukuki açıdan incelenmesi ve istatistiksel olarak yorumlanması vasıtasıyla tartışılmıştır. Taahhüt kararlarının yoğunlaşması her ne kadar pratik anlamda faydalı olarak addedilse de, uzun vadede hukuki belirsizlikleri artıırmıştır. Çünkü, etkin rekabetin tesisi rekabet kurallarının yeknesak ve tutarlı bir biçimde uygulanması yerine, teşebbüsler ile Komisyon arasında varılacak mutabakata bırakılmışırı. Bu kapsamda, taahhüt kararlarının hangi şartlar altında verilmesinin daha uygun olacağına yönelik tartışma ve tavsiyeler sunulmuştur.

Anahtar Kelimeler: AB Rekabet Hukuku, Taahhüt Kararları, Politika Değerlendirmesi.

*Dr. Öğr. Gör. | Ankara Sosyal Bilimler Üniversitesi, Hukuk Fakültesi Ticaret Hukuku A.B.D.

Dr., Social Sciences University of Ankara, Faculty of Law, Commercial Law

fatihbugra.erdem@asbu.edu.tr | ORCID: 0000-0001-8654-2684 | DOI: 10.36484/liberal.870204

Liberal Düşünce Dergisi, Yıl: 26, Sayı: 102, Bahar 2021, ss. 157-170.

Gönderim Tarihi: 28 Ocak 2021 | Kabul Tarihi: 13 Haziran 2021 


\section{Introduction}

The commitment procedure, which allows undertakings to propose adequate commitments for eliminating the risk of being investigated by the competition authorities, has been debated among European competition scholars and experts for more than two decades. In particular, commitment decisions are deemed to be instrumental when potential anticompetitive effects are not clear. It could save time and resources for competition authorities, whereas it does not embrace full investigation and therefore, lead to legal uncertainties due to the lack of developing legal provisions. Concerning the commitment procedure, the turning point for the EU competition law was the establishment of Article 9 of the Regulation 1/2003, which is stated in the following:

"[W]here the Commission intends to adopt a decision requiring that an infringement be brought to an end and the undertakings concerned offer commitments to meet the concerns expressed to them by the Commission in its preliminary assessment, the Commission may by decision make those commitments binding on the undertakings. Such a decision may be adopted for a specified period and shall conclude that there are no longer grounds for action by the Commission."

It is worth noting that the European Commission (hereinafter referred to as "EC" or "Commission") has accepted commitments for a long time. The Commission was able to stop the investigation, reduce the fine or impose interim measures (Wils, 2006: 345-366; Dunne, 2014: 399-444). However, the Commission could not make binding these commitments until the introduction of Article 9 of the Regulation 1/2003, which has been effective from May 2004. In regard to the enforcement of EU competition law, the commitment procedure was revolutionary. Since then, the majority of violation decisions concerning Article 101 and 102 Treaty on the Functioning of the European Union (TFEU) has transformed into commitment decisions. Therefore, the commitment mechanism is not only an effective legal instrument for Article 102 TFEU, but also it can be applied to cases regarding Article 101 TFEU, except for "hard-core" cartel files. For example, the (EC) announced that several undertakings such as Air France, KLM, Alitalia and Delta Airlines made commitments in the context of Article 101 of TFEU with regard to eliminating market entry barriers. ${ }^{1}$ So far, Microsoft (tying) case (2009) is the only fine decision for failure to comply with commitment decision where the fine was set at $€ 561$ million corresponding to 1.02 per cent of Microsoft's turnover in the fiscal year between July 2011 and June 2012. ${ }^{2}$ Hence, one can claim that

1 "Antitrust: Commission accepts commitments by SkyTeam members Air France/KLM, Alitalia and Delta on three transatlantic routes", IP/15/4966, Brussels 12 May 2015.

2 COMMISSION DECISION of 6.3.2013 addressed to Microsoft Corporation relating to a proceeding on the imposition of a fine pursuant to Article 23(2)(c) of Council Regulation (EC) No 1/2003 for 
the commitment mechanism works well in a deterrent way since the EC has the power to impose administrative fine amounted up to ten per cent of undertakings' turnovers in case of not fulfilling the commitment. ${ }^{3}$ Put simply, in case of the failure in such commitments, the EC will fine related undertakings without establishing the actual infringement.

After the effective date of EU Antitrust Regulation (Regulation 1/2003), the EC was equipped by having the authority to make two instrumental types of decisions for the preventive and corrective maintenance of the market through prohibition decisions and commitment decisions in light of Article 7 and Article 9 of the Regulation 1/2003 respectively. That is to say, the EC can either impose a remedy or accept voluntary commitments including structural and behavioural obligations to end the violation. This article statistically observes that the EC had a tendency towards preferring commitment decisions until recently. However, current data demonstrates that this predisposition has evolved to prohibition decisions again. Building on this finding, this paper further discusses the effectiveness of commitment decisions by comparing them with prohibition decisions.

The structure of the paper is presented as follows. This section (section 1) covers introductory remarks on the commitment procedure. Section 2 argues the rationale and effectiveness of commitment decisions. Section 3 presents statistical trends of commitment and prohibition decisions alongside with a critical analysis of trends. Finally, section 4 provides conclusionary remarks and suggestions for the way forward.

\section{Commitment Decisions and Their Rationale}

In the status quo, commitment decisions are deemed as substitutions of prohibition decisions in terms of EU competition law. Until quite recently, commitments were seen as preferred remedies and predominant enforcement tool for the European Commission (Rat, 2015: 527-528), as they enable quicker and resource-efficient reactions to likely anti-competitive conduct. To put it in a different way, while prohibition decisions shall be based on detailed investigations to present the actual infringement, commitment decisions are only pursuant to promises of undertakings to dispel

failure to comply with a commitment made binding by a Commission decision pursuant to Article 9 of Council Regulation (EC) No 1/2003, Article 2; "Antitrust: Commission fines Microsoft for noncompliance with browser choice commitments”, IP/13/196, Brussels 6 March 2013.

3 Council Regulation (EC) No 1/2003 of 16 December 2002 on the implementation of the rules on competition laid down in Articles 81 and 82 of the Treaty (Text with EEA relevance) OJ L 1, 4.1.2003, p. $1-25$ Article 23 
uncorroborated anti-competitive concerns. Hence, commitment decisions can be defined as the quasi-regulatory means of applying competition law, which liberalise the enforcement process to an extent (Botteman and Patsa, 2013: 365). Nevertheless, not all cases are suitable to make commitment decisions; a precise remedy must be offered to fix the market competition. Untested harm theories in novel legal issues, particularly those are related to high-tech markets (as such in Rambus, Intel and Microsoft) should not be resolved via commitment decisions (Botteman and Patsa, 2013: 347), since precedents would likely be wrongful unless determining exactly which actions lead to anticompetitive consequences.

Commitment procedure is advantageous for businesses in terms of reducing the risk of heavy fines and litigation costs, which would likely occur from follow-on lawsuits. On the other hand, the Commission also takes advantage of commitment decisions, as they are quicker solutions than enforcement decisions (Jenny, 2015: 712-713). Mariniello showed this incentive by averaging out the page numbers of decisions issued from 2004 to 2013; and illustrated that there was an average of 21 pages per commitment decision, whereas 160 pages per prohibition decisions (Mariniello, 2014). The reason why there is a huge difference between average page numbers is that the Commission does not need to articulate a harm theory. Commitment decisions are also advantageous for the EC, since they are quite flexible with a broad margin of discretion and no procedural limit.

The commitment implementation in non-cartel violation decisions has been applied to remarkable amount of cases. It is consequently worth arguing the effectiveness of commitment decisions, in which the EC is equipped with wide discretion and bargaining power. Since the EC does not need to establish a theory of harm, the commitment procedure paves the way for obscurity for following complex cases (Stones, 2019: 361-399). However, alongside of its rewards, commitment decisions have drawbacks in terms of both the Commission and undertakings. For example, undertakings can fend off competition investigations by making inadequate commitments with the advantage of information asymmetry. The Commission, on the other hand, can also ask for disproportionate commitments using the threat of imposing large penalties (Wagner-von Papp, 2019). Moreover, despite the fact that commitment decisions are mostly considered to be advantageous to offer quick solutions, the time course of investigations is also open to debate, as commitment procedures do not always expedite to overcome the anticompetitive concern. There were many examples that might be regarded as dilatory motions. For example, the time between the commitment decision and final decision was 
around 50 months in Google Search, 28 months in Rambus, 24 months in Microsoft, and 17 months in IBM cases. Overall, there is an exigency to revise commitment procedures.

More importantly, in practical terms, intensifying commitment decisions means the transition from legalistic competition law to competition law-as-regulation; this shift leads to the politicisation of competition law, and consequently leaves this niche branch of law weak under political pressures (Dunne, 2014: 440-442; First, 1995: 11-12). From another perspective, pairwise negotiations between the Commission and an undertaking in question increases the legal uncertainty since the Commission does not need to present any robust statement with a developed harm theory if negotiations are successful. This shows that commitment decisions have no benefit in identifying violations and stating the law (Plank, 2016: 417). This being the case, legal uncertainty about which behavior would constitute a violation has inevitably increased. As a result, a decentralized enforcement was emerged in EU competition law (Rat, 2015: 532; Botteman and Patsa, 2013: 357-365; McGeown and Orologas, 2013; 4). In this context, Stones (2019: 365) argued the necessity of establishing an administrative-judiciary bridge in the implementation of EU competition law by indicating that courts should take a supervisory role as an independent reviewer for the implementation of the formal rule of law and the provision of normative comprehensibility. He accordingly stated as follows:

"[E]nforcement in the form of ad hoc, subject-specific decisions without any discernible generalized norms to structure future determinations has undermined the systematic legal certainty of EU competition law, as authoritatively deduced by the Courts from Articles 101 and 102 TFEU” (Stones, 2019:399).

In light of all the facts mentioned so far, extensive application of commitment decisions by the Commission has reduced the marginal benefit to be gained from this tool and moreover, it poses more legal uncertainty risk than expected benefit. Therefore, commitment decisions should not be seen as the first easy solution that comes to mind and should be applied to the extent on the condition that it does not allow legal uncertainty. The statistical trend on case law seems that the EC has started redressing itself in this manner.

\section{Commitment Decisions v. Prohibition Decisions: Statistical Trends}

The way of commitment has been mostly preferred since 2004 due to its several benefits. For example, it provides procedural efficiency by expediting 
oral/written adversarial proceedings (Alrosa, para 35). Besides, the commitments have the capacity to make a faster and more direct impact on the market even at the beginning of the investigation. As well as this is a collaborative process involving companies, it will be easier for companies to adapt to their commitments by observing their own terms (European Commission, 2014: 3). However, in case of serious and irrevocable competition violations such as cartels, 'cease-and-desist' orders are given under Article 7 terms (European Commission, 2014: 1-4). Apart from this, it can be seen that the Commission generally accepts commitments offered as such in cases of Swedish Interconnectors (2010) and Amazon e-book (2013). The Commission accepted commitments of TenneT TSO GmbH in regard to the increase of electricity trading capacity between Denmark and Germany in DE/DK Interconnector (2018). In the Amazon e-book case (2013), commitments offered by Amazon. com were found suitable to address initial concerns, which were concerning the decrease of competitive capacity in competing e-book suppliers and retailers. ${ }^{4}$ According to decisions taken so far, commitments proposed in CISAG agreements (2008), Google Search - Shopping (2017), and MasterCard II (2019) cases were rejected and culminated in Article 7 orders.

As seen the table below, from 2004 to 2020, there were 41 commitment decisions and 41 prohibition decisions. One can interpret this balance as an adaption period but on the other hand, one can also see the downward tendency regarding the commitment decisions.

4 Summary of Commission Decision of 4 May 2017 relating to a proceeding under Article 102 of the Treaty on the Functioning of the European Union and Article 54 of the EEA Agreement (Case AT.40153 - E-Book MFNS and related matters) (notified under document C(2017) 2876) Article 17-23. 
The Downhill Trend in Commitment Mechanism of EU Competition Law | 163

Table 1 Commission antitrust-only decisions under Article 7 and Article 9 of Regulation 1/2003 between 2004-20195

\begin{tabular}{|c|c|c|}
\hline Year & Commitments Decisions & Prohibition Decisions \\
\hline 2004 & & $\begin{array}{l}37792 \text { Microsoft } \\
37980 \text { Souris Bleue/TOPPS + Nin- } \\
\text { tendo } \\
38096 \text { PO/Clearstream (Clearing } \\
\text { and settlement) } \\
38662 \text { GDF } \\
38549 \text { Barême d'honoraires de } \\
\text { l'Ordre des Architectes belges }\end{array}$ \\
\hline 2005 & $\begin{array}{l}37214 \text { DFB } \\
39116 \text { Coca-Cola }\end{array}$ & $\begin{array}{l}36623 \text { SEP at autres / Automobiles } \\
\text { Peugeot SA } \\
36820 \text { SEP at autres / Automobiles } \\
\text { Peugeot SA } \\
37275 \text { SEP at autres / Automobiles } \\
\text { Peugeot SA }\end{array}$ \\
\hline 2006 & $\begin{array}{l}38173 \text { The Football Association } \\
\text { Premier League Limited } \\
38348 \text { REPSOL C.P.P. SA - Dist- } \\
\text { ribution de Carburants et Com- } \\
\text { bustibles } \\
38381 \text { ALROSA + DBCAG (part } \\
\text { of de Beers group) + City and } \\
\text { West East (part of de Beers } \\
\text { group) } \\
\mathbf{3 8 6 8 1} \text { Cannes Agreement }\end{array}$ & $\begin{array}{l}37507 \text { Generics/Astra Zeneca } \\
38113 \text { Prokent/Tomra }\end{array}$ \\
\hline 2007 & 37966 Distrigaz & $\begin{array}{l}34579 \text { MasterCard I } \\
37860 \text { Morgan Stanley Dean Witter/ } \\
\text { Visa } \\
38606 \text { GROUPEMENT DES CARTES } \\
\text { BANCAIRES “CB" } \\
\mathbf{3 8 7 8 4} \text { Telefonica S.A. (broadband) }\end{array}$ \\
\hline 2008 & $\begin{array}{l}39388 \text { German electricity } \\
\text { wholesale market } \\
39389 \text { German Electricity } \\
\text { Balancing Market }\end{array}$ & 38698 CISAC Agreement \\
\hline
\end{tabular}

5 Data was collected via European Commission's website through searching "commitments decisions" and "prohibition decisions in the case search tool" between 2004-2020 by excluding cartels. 
164 | Fatih Buğra Erdem

\begin{tabular}{|c|c|c|}
\hline 2009 & $\begin{array}{l}38636 \text { Rambus } \\
39316 \text { GDF foreclosure } \\
39402 \text { RWE gas foreclosure } \\
39416 \text { Ship Classification } \\
39530 \text { Microsoft (Tying) }\end{array}$ & 37990 Intel \\
\hline 2010 & $\begin{array}{l}39315 \text { ENI } \\
39317 \text { E.On gas foreclosure } \\
39351 \text { Swedish Interconnectors } \\
39386 \text { Long term electricity } \\
\text { contracts in France } \\
39596 \mathrm{BA} / \mathrm{AA} / \mathrm{IB}\end{array}$ & $\begin{array}{l}39510 \text { Ordre National des Pharma- } \\
\text { ciens en France (ONP) }\end{array}$ \\
\hline 2011 & $\begin{array}{l}39592 \text { Standard and Poor's } \\
39692 \text { IBM - Maintenance } \\
\text { services }\end{array}$ & 39525 Telekomunikacja Polska \\
\hline 2012 & $\begin{array}{l}39230 \text { Rio Tinto Alcan } \\
39654 \text { Reuters Instrument Co- } \\
\text { des } \\
39736 \text { Siemens/Areva }\end{array}$ & \\
\hline 2013 & $\begin{array}{l}39595 \text { Continental/United/ } \\
\text { Lufthansa/Air Canada } \\
39678 \text { Deutsche Bahn I () } \\
\text { (non-confidential version) } \\
39731 \text { Deutsche Bahn II () } \\
\text { (non-confidential version) } \\
39727 \text { CEZ } \\
39847 \text { Amazon Ebooks }\end{array}$ & $\begin{array}{l}39226 \text { Lundbeck } \\
39685 \text { Fentanyl } \\
39839 \text { Telefónica and Portugal } \\
\text { Telecom }\end{array}$ \\
\hline 2014 & $\begin{array}{l}39939 \text { Samsung - Enforcement } \\
\text { of UMTS standard essential pa- } \\
\text { tents }\end{array}$ & $\begin{array}{l}39523 \text { Slovak Telekom } \\
39612 \text { Perindopril (Servier) } \\
39984 \text { OPCOM / Romanian Power } \\
\text { Exchange } \\
39985 \text { Motorola - Enforcement of } \\
\text { GPRS standard essential patents }\end{array}$ \\
\hline 2015 & $\begin{array}{l}39767 \text { BEH Electricity } \\
39964 \mathrm{AF}-\mathrm{KL} / \mathrm{DL} / \mathrm{AZ}\end{array}$ & \\
\hline 2016 & $\begin{array}{l}39754 \text { CDS - Information } \\
\text { market } \\
39850 \text { Container Shipping }\end{array}$ & 39759 ARA foreclosure \\
\hline
\end{tabular}


The Downhill Trend in Commitment Mechanism of EU Competition Law | 165

\begin{tabular}{|c|c|c|}
\hline 2017 & $\begin{array}{l}40153 \text { E-book MFNs and } \\
\text { related matters (Amazon) }\end{array}$ & $\begin{array}{l}39740 \text { Google Search (Shopping) } \\
39813 \text { Baltic Rail } \\
40208 \text { International Skating Union's } \\
\text { Eligibility Rules }\end{array}$ \\
\hline 2018 & $\begin{array}{l}39816 \text { Upstream gas supplies } \\
\text { in Central and Eastern Europe } \\
40461 \text { DE/DK Interconnector }\end{array}$ & $\begin{array}{l}40099 \text { Google Android } \\
40181 \text { Philips (vertical restraints) } \\
40182 \text { Pioneer (vertical restraints) } \\
40428 \text { Guess } \\
40465 \text { Asus (vertical restraints) } \\
40469 \text { Denon \& Marantz (vertical } \\
\text { restraints) }\end{array}$ \\
\hline 2019 & $\begin{array}{l}39398 \text { Visa MIF } \\
40023 \text { Cross-border access to } \\
\text { pay-TV } \\
40049 \text { MasterCard II }\end{array}$ & $\begin{array}{l}40049 \text { MasterCard II } \\
40134 \text { AB InBev Beer Trade Restri- } \\
\text { ctions } \\
40432 \text { Character Merchandise } \\
\mathbf{4 0 4 3 6} \text { Ancillary sports merchandise }\end{array}$ \\
\hline 2020 & $\begin{array}{l}40335 \text { Romanian Gas } \\
\text { Interconnectors }\end{array}$ & $\begin{array}{l}40528 \text { Melia (Holiday Pricing) } \\
40433 \text { Film Merchandise }\end{array}$ \\
\hline
\end{tabular}

To be more precise, the number of commitment and prohibition decisions is shown below.

Table 2 The Number of Commitment/Prohibition Decisions between 2004-2020

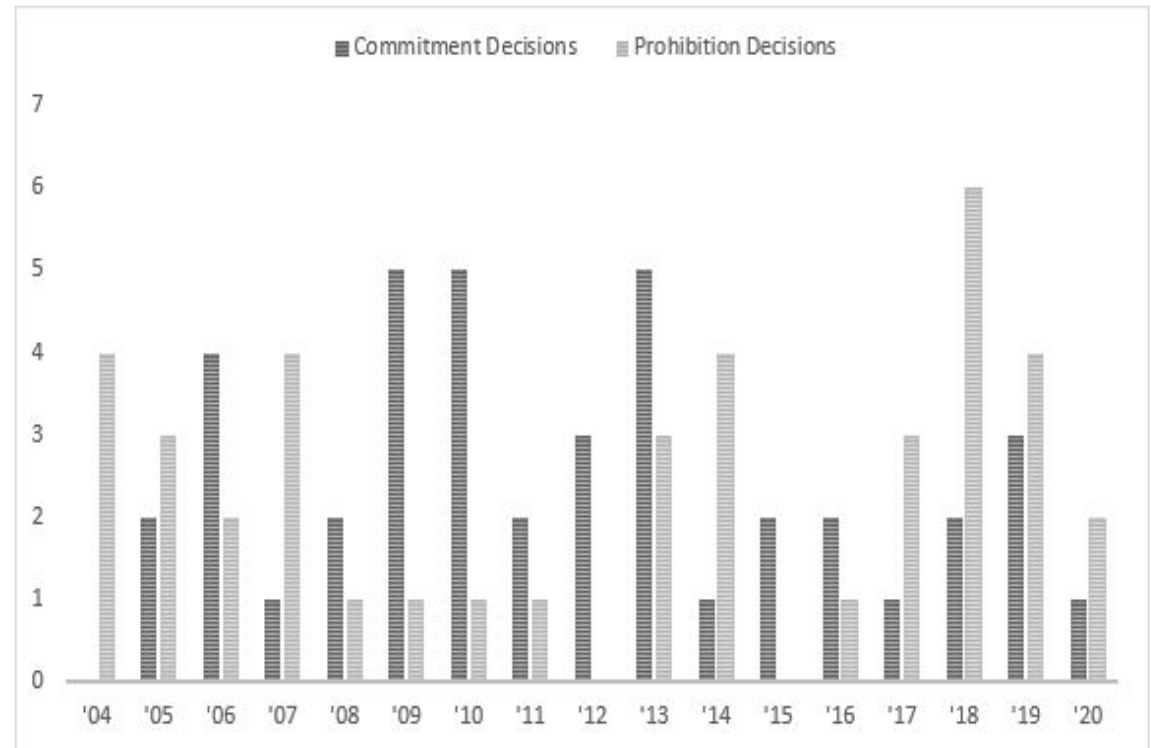


The raw data provided by the Table 1 and Table 2 is interpreted in two different ways. First, Table 3 (shown below) is created to demonstrate the trend line to find when the decrease in the number of commitment decisions in proportion to prohibition decisions began. A polynomial trendline was employed, as the large dataset has oscillating values having more than one descent and ascent.

Table 3 The Percentage of Commitment Decisions over Prohibition Decisions and the Polynomial Trendline

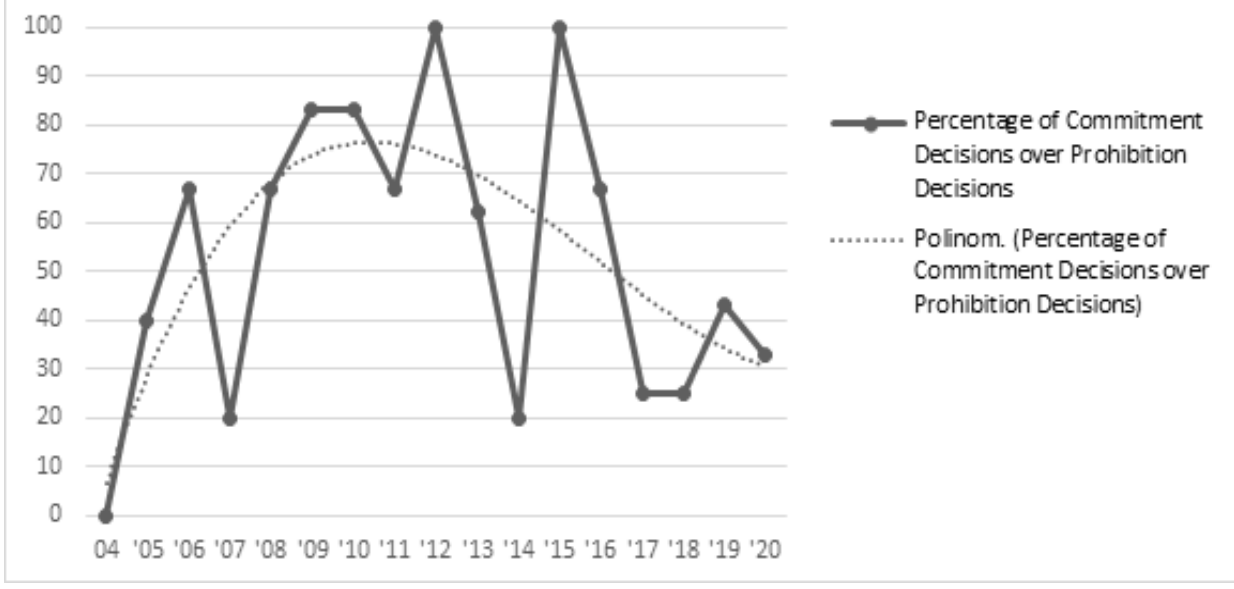

From the Table 3 it can be accordingly seen that the decreasing tendency in terms of issuing commitment decisions started after 2011. In this context, the data is analysed from a different perspective with Table 4 (shown below), which is formed by dividing the data into 5 different time intervals for a better interpretation of events. It is very important to state that Table 4 also verifies Table 3 in the framework of beginning the decline period. 


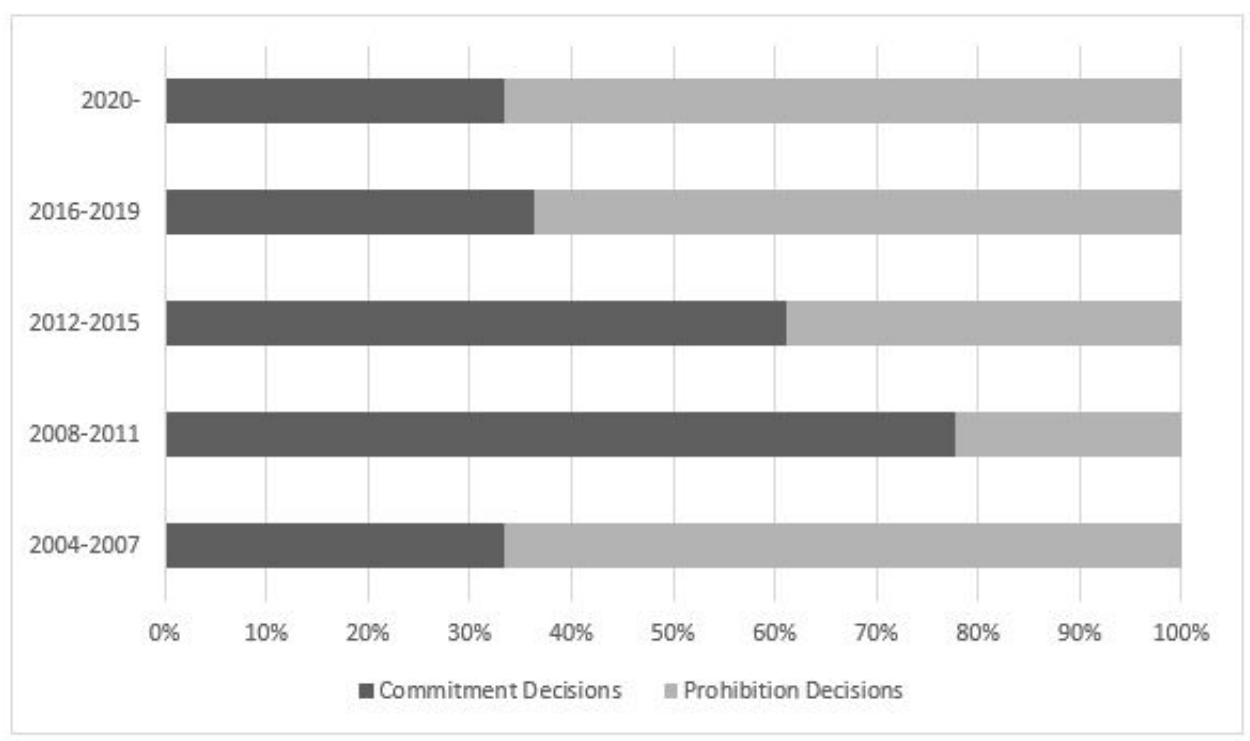

As far as the paper concerned, there is no specific event that can be seemed as a turning point in 2011. In this regard, when the developments in case law and regulations are taken into consideration, the milestones are set as (a) the commitment decisions in the Alrosa in 2006, (b) the Google Search (Shopping) case in 2014, and (c) the prohibition decision in Google Android case in 2018 respectively.

According to Jenny, the Alrosa case was the reason why commitment decisions were over-applied. The Commission's approach, in this case, was clearly in line with preferring to make commitment decisions through employing an ex-ante regulatory approach. ${ }^{6}$ Therefore, commitment decisions became primary enforcement tools and prohibition decisions stayed in the background. ${ }^{7}$ Consequently, the commitment mechanism came into more prominence. However, in recent times, the trend is changed towards again prohibition decisions. Particularly, the shift towards adapting infringement decisions once more began by the Google Shopping case, where the Commission took a more sceptical approach (During the case Google's commitments were rejected three times) in 2014 through indicating that commitment procedure is always not the quickest and resource-efficient way if an anticompetitive

6 Frederic Jenny, 'Worst Decision of the EU Court of Justice: The Alrosa Judgment in Context and the Future of Commitment Decisions' (2015) 38 Fordham International Law Journal 701-70.

7 Frederic Jenny, 'Worst Decision of the EU Court of Justice: The Alrosa Judgment in Context and the Future of Commitment Decisions' (2015) 38 Fordham International Law Journal 702; Damien Gerard, 'Negotiated Remedies in the Modernization Era: The Limits of Effectiveness' in Philip Lowe, Mel Marquis and Giorgio Monti, European Competition Law Annual 2013: Effective and Legitimate Enforcement of Competition Law (Hart Publishing 2016) 139-185. 
conduct likely leads to irreparable harm to the market. ${ }^{8}$ Afterward, the EC's approach was cemented with the Google Android prohibition decision made in 2018. In this case, Google submitted a letter showing its intention to implement commitments as per Article 9 of Regulation 1/2003. However, the EC informed Google to continue its proceeding under Article 7 of Regulation 1/2003. ' It can be identified two likely reasons why Google could not propose any commitments in the Android case. First, the argument of Google was almost identical with the rejected assertion in Microsoft (tying) case and consequently, it was likely to foresee similar judgments. Second, the Commission altered its approach towards commitment decisions. Google had already been faced high amount of fine by the prohibition decision even though it proposed detailed commitments in Google Shopping case. All these reasons can explain the increasing and decreasing tendencies of commitment decisions.

\section{Concluding Remarks}

Although the commitment mechanism provides great convenience in assuaging the Commission's concerns, its implementation causes inconveniences in a way that increases the legal uncertainty. However, it would be more accurate to accept the commitments in the presence of a well-established caselaw on the specific subject, as the commitment procedure is open for abuses by both undertakings and the Commission. In this regard, commitment decisions have fallen in value in due course as shown by statistical trends and case law review. Therefore, it is apparent that the Commission's increased tendency of applying Article 9 of the Regulation 1/2003 is a kind of self-correction. It is difficult to predict how this inclination will change in the years ahead, but it would always be necessary to initially address prohibition decisions, given that there are still many gray areas such as digitalisation of law and increased cross-border transactions.

\section{References}

Botteman, Y. and Patsa, A. (2013). Towards a More Sustainable Use of Commitment Decisions in Article 102 TFEU Cases. Journal of Antitrust Enforcement, 1(2), 347-74.

Case T-30/89, Hilti AG v. Commission. (1991). E.C.R II-1445.

Case COMP/B-2/38.381, De Beers. (2006). C(2006) 521.

Commission Decision of 6.3.2013 addressed to Microsoft Corporation relating to a proceeding on the imposition of a fine pursuant to Article 23(2)(c) of Council Regulation

8 Florian Wagner-von Papp, 'Commitment decisions: An overview of EU and national case law' (e-Competitions Special Issue Commitment Decisions, 30 May 2019)

9 CASE AT.40099 Google Android [2018] C(2018) 4761 final, Para 32 
(EC) No $1 / 2003$ for failure to comply with a commitment made binding by a Commission decision pursuant to Article 9 of Council Regulation (EC) No 1/2003.

Commission Decision of 7.12.2018 relating to a proceeding under Article 102 of the Treaty on the Functioning of the European Union and Article 54 of the EEA Agreement Case AT.40461 - DE/DK Interconnector, C(2018) 8132 final.

Commission Decision of 27.6.2017 relating to proceedings under Article 102 of the Treaty on the Functioning of the European Union and Article 54 of the Agreement on the European Economic Area (AT.39740 - Google Search (Shopping)), C(2017) 4444 final.

Commission Decision of 18.7.2018 relating to a proceeding under Article 102 of the Treaty on the Functioning of the European Union (the Treaty) and Article 54 of the EEA Agreement (AT.40099 - Google Android), C(2018) 4761 final.

Council Regulation (EC) No 1/2003 of 16 December 2002 on the implementation of the rules on competition laid down in Articles 81 and 82 of the Treaty (Text with EEA relevance) OJ L 1, 4.1.2003, Article 23.

Dunne, N. (2014). Commitment Decisions in EU Competition Law. Journal of Competition Law and Economics, 10(2), 399-444.

European Commission. (2013). Antitrust: Commission fines Microsoft for non-compliance with browser choice commitments. IP/13/196.

European Commission. (2015). Antitrust: Commission accepts commitments by SkyTeam members Air France/KLM, Alitalia and Delta on three transatlantic routes. IP/15/4966.

European Commission. (2009). Guidance on the Commission's enforcement priorities in applying Article 82 of the EC Treaty to abusive exclusionary conduct by dominant undertakings. Official Journal C 45/7.

European Commission. (2014). To commit or not to commit?: Deciding between prohibition and commitments. Competition Policy Brief 3.

First, H. (1995). Is Antitrust Law?. Antitrust, 10, 11-12.

Gerard, Damien (2016), "Negotiated Remedies in the Modernization Era: The Limits of Effectiveness", Philip Lowe, Mel Marquis and Giorgio Monti (eds), European Competition Law Annual 2013: Effective and Legitimate Enforcement of Competition Law, Hart Publishing, p. 139-185.

Jenny, F. (2015). Worst Decision of the EU Court of Justice: The Alrosa Judgment in Context and the Future of Commitment Decisions", Fordham International Law Journal, 38, 701 70.

Mariniello, M. (2014). Commitments or prohibition? The EU antitrust dilemma. Bruegel Policy Brief, 2014/1, 7.

McGeown, P. and Orologas, J. (2013). You made a Pledge, then keep your promise: Article 9 Commitments decisions in European Antitrust Law. CPI Antitrust Chronicle, 3, 4.

Plank, R. (2016). Antitrust and Financial Services in the EU: Commitments in Credit Default Swaps (CDS). Zeitschrift für Wettbewerbsrecht, 4, 417.

Rat, D. (2015). Commitment Decisions and Private Enforcement of EU Competition Law: Friend or Foe?. World Competition, 38(4), 532.

Stones, R. (2019). Commitment Decisions in EU Competition Enforcement: Policy Effectiveness v. the Formal Rule of Law. Yearbook of European Law, 38(1), 361. 
Summary of Commission Decision of 6 March 2013 relating to a proceeding on the imposition of a fine pursuant to Article 23(2)(c) of Council Regulation (EC) No 1/2003 for failure to comply with a commitment made binding by a Commission decision pursuant to Article 9 of Council Regulation (EC) No 1/2003 (Case COMP/39.530 - Microsoft (Tying)), C(2013) 1210 final.

Summary of Commission Decision of 4 May 2017 relating to a proceeding under Article 102 of the Treaty on the Functioning of the European Union and Article 54 of the EEA Agreement (Case AT.40153 - E-Book MFNS and related matters) (notified under document C(2017) 2876.

Van Bael and Bellis. (2018). Abuse of Dominant Position. VBB on Competition Law, 12.

Wagner-von Papp, F. (2019). Commitment decisions: An overview of EU and national case law. e-Competitions Special Issue Commitment Decisions, https://www.concurrences. com/en/bulletin/special-issues/commitment-decisions/commitment-decisions-anoverview-of-eu-and-national-case-law-en (Accessed 21 January 2021).

Wils, W. (2006). Settlements of EU Antitrust Investigations: Commitment Decisions under Article 9 of Regulation No 1/2003. World Competition, 29(3), 345-66. 